\title{
Load Frequency Control of Single Area Thermal Power Plant Using Type 1 Fuzzy Logic Controller
}

\author{
Rajendra Fagna \\ Department of Electrical Engineering, Rajasthan Technical University, Kota, India
}

\section{Email address:}

rajendrafagna92@gmail.com

\section{To cite this article:}

Rajendra Fagna. Load Frequency Control of Single Area Thermal Power Plant Using Type 1 Fuzzy Logic Controller. Science Journal of Circuits, Systems and Signal Processing. Vol. 6, No. 6, 2017, pp. 50-56. doi: 10.11648/j.cssp.20170606.11

Received: November 24, 2017; Accepted: December 15, 2017; Published: January 16, 2018

\begin{abstract}
In this paper, a type 1 Fuzzy controller is composed for solving change in load frequency problem of single area thermal power system. The performances of type 1 fuzzy controller have been demonstrated for comparing the performances of other published paper PID controller such as Ziegler Nichols method. A single area non-reheat thermal power plant with Fuzzy controller is simulated in MATLAB/SIMULINK platform due to a step change in load demand. The proposed fuzzy controller gives better dynamic responses of the power system in terms of Settling time, Peak Overshoot and Peak Undershoot.
\end{abstract}

Keywords: Load Frequency Control (LFC), Thermal Power Plant, Proportional-Integral-Derivative (PID) Controller, Fuzzy Logic Controller, Frequency Deviation

\section{Introduction}

For a utility of power system is essential to keep the continuous supply of electric power to the consumer without any disturbances. For an equilibrium, the power system is to maintain a balance between load demand of the consumer and power generated of the power plant [1]. Due to increasing the complexity in the world, the power demand is also increases. The load demand of the consumer increases due to a frequency is changed from its nominal value. So, it is necessary to maintain the system frequency is to be constant. LFC is one of the basic strategies to achieve balancing between the real power and reactive power.

The conventional method of PID controllers such as Ziegler Nichols [2] method, Tyreus-Luyben method, Cohen-Coon method, Fertik method and Integral Model Control method are used for controlling the load frequency of power system.

Fuzzy logic controller is one of the intelligent controller for controlling the load frequency of power system. Fuzzy logic controller not only improves the dynamic performance but also reduces the steady state error [3].

Authors Pradhan et al. [4] have proposed the automatic generation control using a Fuzzy PID controller for multi area power system and the parameters of Fuzzy PID controller optimized by using a Firefly Algorithm. Kumar [5] have studied on the LFC of two area interconnected thermal power plant using fuzzy logic controller and the responses of fuzzy controller compared with P, PI and PID controllers. Nagajyothi have reported on the fuzzy logic controller for LFC of multi area power system. Meena et al. have designed and analysis of fuzzy PID controller for interconnected power system and compared the results of PI, PID and Fuzzy PID for different values of speed regulation.

Kashyap et al. [6] have designed a fuzzy PI controller for improving the dynamic performance of two area hydropower system and results have been demonstrated for comparing PI and Fuzzy PI. Prajapati [7] have comparatively studied on fuzzy logic and Integral controller. Daood et al. [8] studied on improving the grid stability of interconnected wind power system using Fuzzy PID controller. For large power demand, more power plant is interconnected to each other. Ozkop et al. [9] designed a Fuzzy Logic PI controller for controlling the load frequency of four area power plant and for superiority of controller the performances of fuzzy PI controller compared with PI controller for LFC of multi area power system and the parameters of fuzzy PID are optimized by Genetic Algorithm.

Sathans [10] have proposed a fuzzy PID controller for controlling load frequency of two area power system considering generation rate constraints. Lal [11] have presented an AGC for multi area power system using fuzzy 
logic PI and PID controller. A comparative study on LFC of single area using fuzzy logic and optimal controllers has been proposed by Samuel N [12]. Cam et al. [13] have designed a Fuzzy logic controller for improving the responses of two area power system and the parameters of the controllers are tuned by using Genetic Algorithm.

Nayak et al. [14] have composed a fuzzy PID controller for AGC of two area interconnected power system and the parameters of the Fuzzy PID controller are tuned using Teaching Learning Based Optimization Algorithm. Sambariya et. al. [15] have designed an adaptive neuro fuzzy controller for controlling the change in frequency of multi area power system. Nath et. al. [16] have analyzed the automatic generation control of single and two area power system using fuzzy controller. Sambariya et al. [17] have presented fuzzy logic controller for LFC of multi area power system. Sahu et al. [18] have employed fuzzy PID controller for controlling load frequency of multisource power system using hydrid LUS-TLBO algorithm. Yesil [19] have improving the performances of LFC using interval type-2 fuzzy PID controller and the parameter of fuzzy PID controller optimized by using Big Bang-Big Crunch optimization techniques. Pothiya et al. [20] have used optimal fuzzy logic PID controller for solving load frequency problem in power system. Rakhtala [21] have designed a fuzzy PID controller for polymer exchange membrane fuel cell.

The proposed work to presents a study of LFC of single area non-reheat thermal power system. The type 1 fuzzy controller used for controlling the load frequency of power system. The proposed controller gives better dynamic performances in terms of time specification.

This paper is prepared in 5 sections. The problem formulation with system description is presented in section 2 . The controllers used for change in load frequency problem is presented in section 3. The simulation and comparative performances in terms of Settling time, Peak Overshoot, Undershoot and performances table as presented in section 4 . The conclusion of this work is presented in section 5 and last consists of nomenclature and references

\section{Problem Formulation}

System description

A single area non -reheat thermal power plant comprising of following components such as a governor, turbine, a generator and load with speed regulation feedback in the system [22]. A step load change in power demand given to the generator. The transfer function of the blocks used for single area LFC [23].

a. Governor transfer function

$$
G_{G}(s)=\frac{1}{1+s T_{G}}
$$

b. Turbine transfer function

$$
G_{T}(s)=\frac{1}{1+s T_{T}}
$$

c. Combined inertia of rotating mass and load transfer function

$$
G_{L}(s)=\frac{K_{P}}{1+s T_{P}}
$$

d. Droop characteristics

$$
1 / \boldsymbol{R}
$$

The model of single area non-reheat thermal power plant with type 1 fuzzy controller as shown in Figure 1.

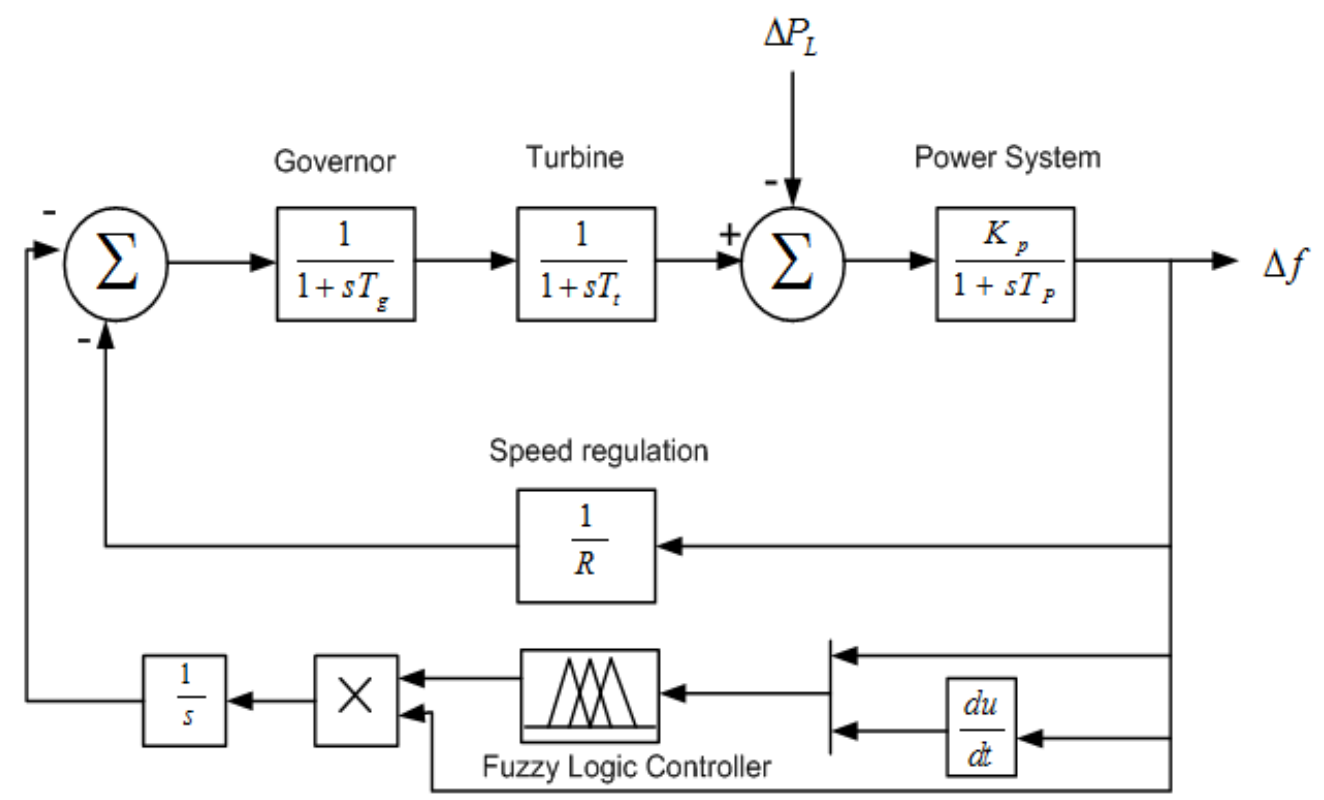

Figure 1. Block diagram of single area non-reheat thermal power plant with type 1 fuzzy logic controller. 


\section{Controllers}

Two different controllers used for controlling the load frequency of single area thermal power plant. These two methods are conventional PID controller and fuzzy logic controller.

\subsection{PID Controller}

The Proportional Integral Derivative (PID) controller structure is the most widely used in control applications. The PID controller has three parameters $\boldsymbol{K}_{p}, \boldsymbol{K}_{I}$ and $\boldsymbol{K}_{\boldsymbol{D}}$. These parameters are tuned by using optimization techniques. PID controller are used when the system stability and fast responses are needed. The PID controller transfer function as in Eq. 5. The prototype of PID controller is shown in Figure 2.

$$
P I D=K_{p}+\frac{K_{i}}{s}+K_{d} s
$$

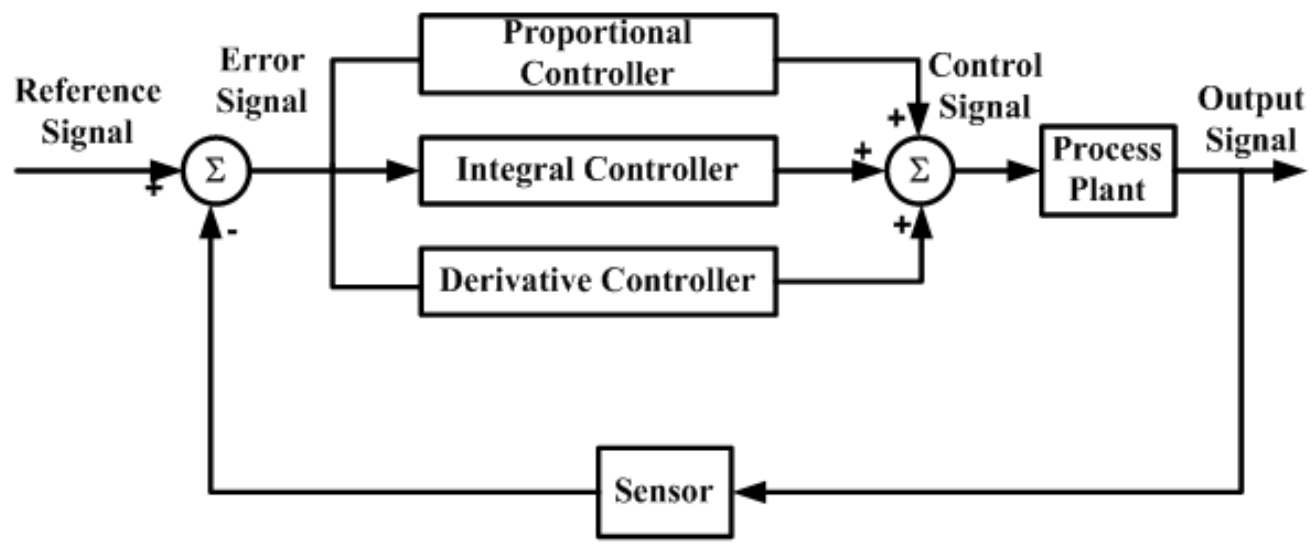

Figure 2. Prototype of conventional PID controller.

\subsection{Fuzzy Logic Controller}

Fuzzy logic controller is based on a logical system called fuzzy logic. The fuzzy logic controller works on a three process such as fuzzification, fuzzy rule base and defuzzification. The structure of fuzzy logic controller as shown in Figure 3.

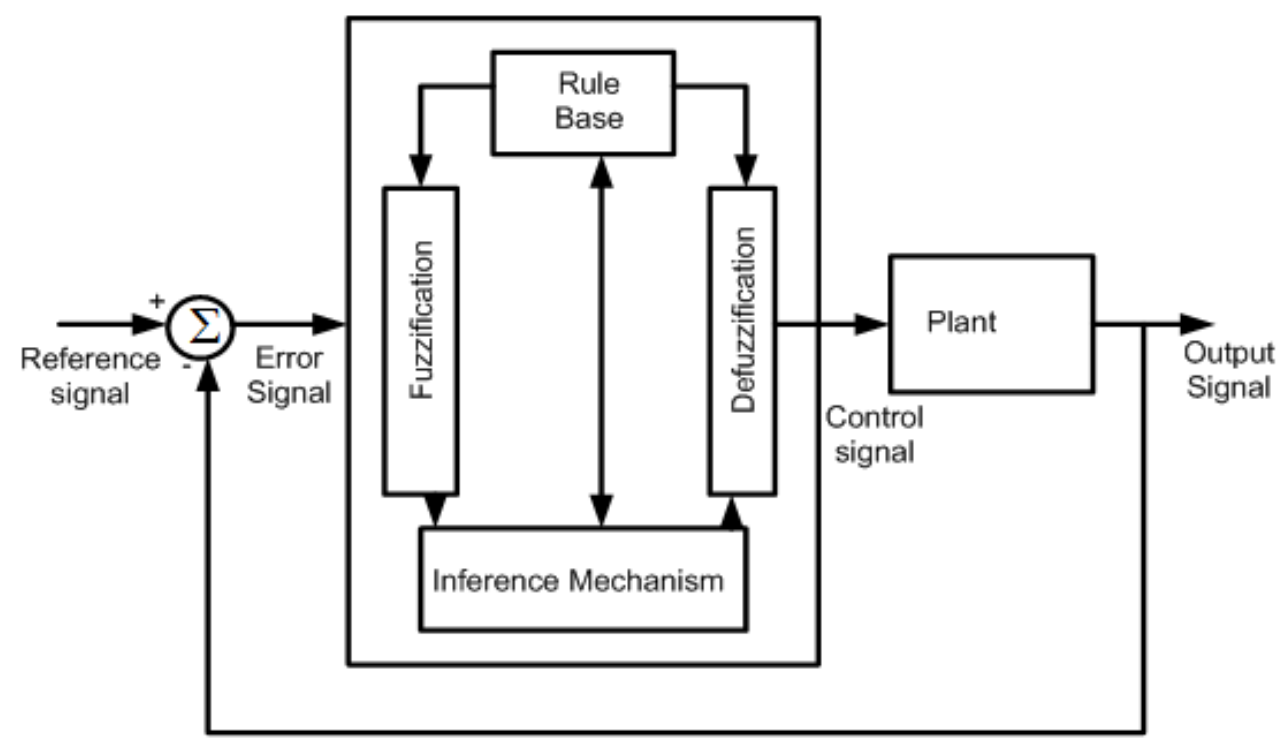

Figure 3. Fuzzy logic controller.

\subsubsection{Fuzzification}

Fuzzification is the process of converting real value input signal into a linguistic variable. The real value inputs for a single area thermal power system is error and derivative of error. Mamdani type fuzzy interface platform provide between the inputs signal and the output signal as shown in
Figure 4.

For both input signals, the five-linguistic variable are used as NL (Negative Large), NS (Negative Short), ZZ (Zero), PS (Positive Short) and PL (Positive Large). For output signal the five linguistic variables are $\mathrm{S}$ (Short), M (Medium), L (Large), VL (Very Large) and VVL (Very-Very Large). 


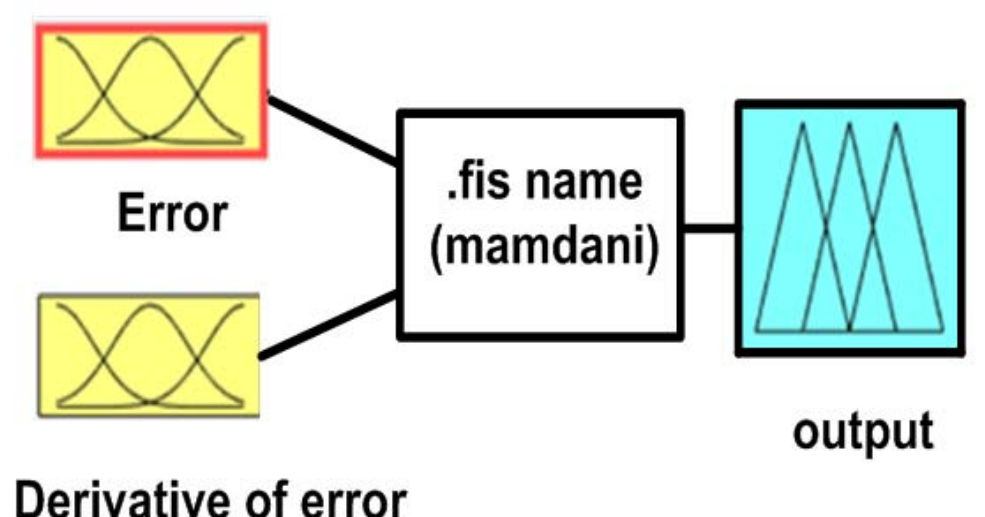

Figure 4. Fuzzy Interface block.

\subsubsection{Fuzzy Rule Base}

The fuzzy rule base comprises of fuzzy if- then rules. The fuzzy rule may contain fuzzy variable and fuzzy subset categorized by member function. The fuzzy rule base as given in Table 1. The rules are generated in this manner: if the linguistic variable of error is NL and the linguistic variable of derivative of error is NL then the output control signal variable is $\mathrm{S}$. Using these linguistic variable and member function, total number of 25 rules are generated.

Table 1. Fuzzy Rule Base table.

\begin{tabular}{|c|c|c|c|c|c|}
\hline$\dot{e}(t)$ & NL & NS & $\mathbf{Z Z}$ & PS & PL \\
\hline NL & $\mathrm{S}$ & $\mathrm{S}$ & M & M & $\mathrm{L}$ \\
\hline NS & $\mathrm{S}$ & M & M & $\mathrm{L}$ & VL \\
\hline ZZ & M & M & $\mathrm{L}$ & VL & VL \\
\hline PS & M & $\mathrm{L}$ & VL & VL & VVL \\
\hline PL & $\mathrm{L}$ & VL & VL & VVL & VVL \\
\hline
\end{tabular}

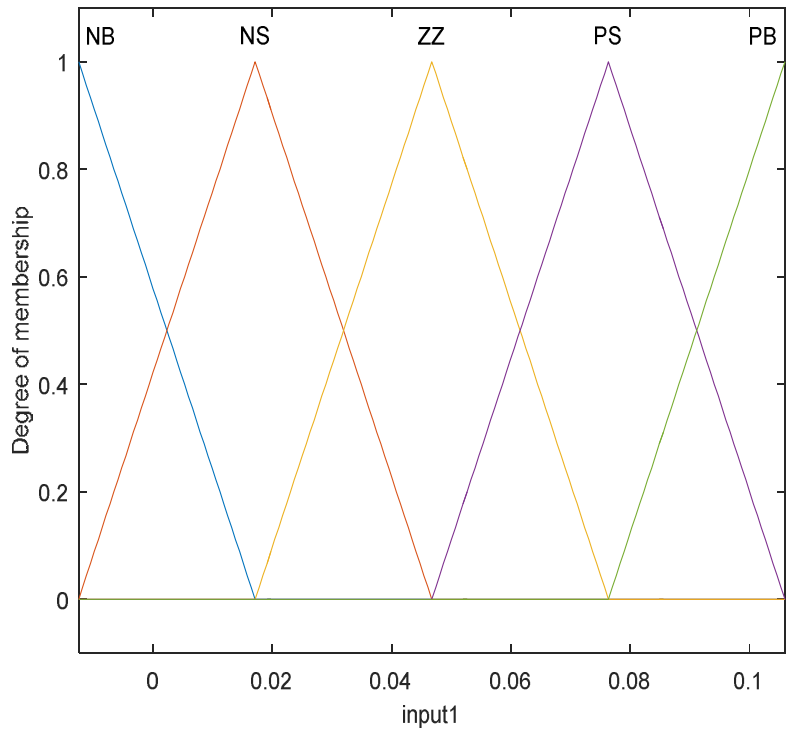

Figure 5. Triangular Membership function for frequency deviation.

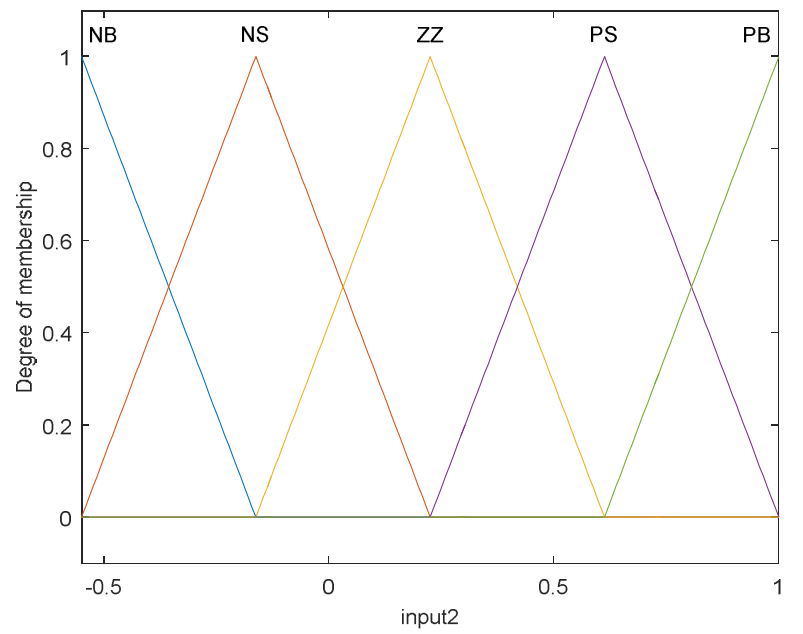

Figure 6. Triangular Membership function for derivative of frequency deviation.

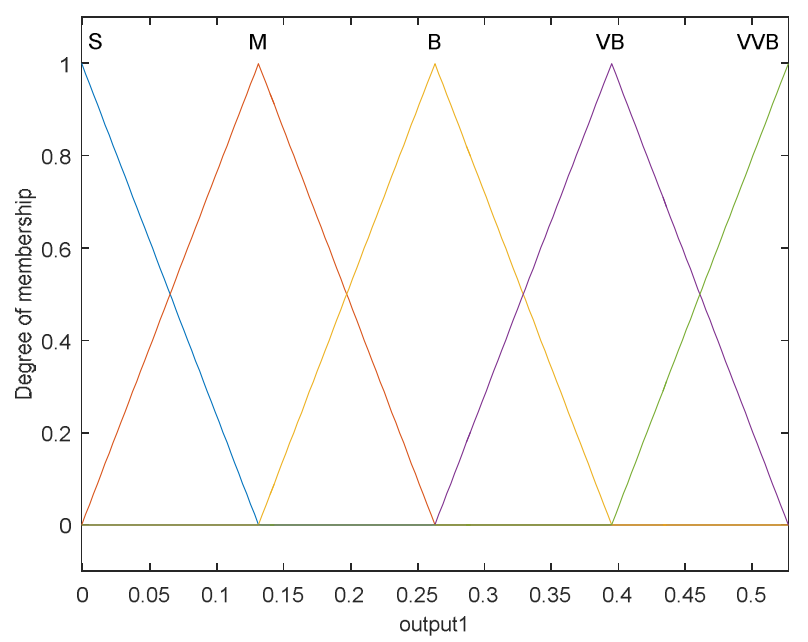

Figure 7. Triangular Membership function for output signal.

The samples of these rules given below:

If (INPUT1 is NL) and (INPUT2 is NL) then (OUTPUT1 is $S$ )

If (INPUT1 is NL) and (INPUT2 is NS) then (OUTPUT1 is $S$ )

If (INPUT1 is NL) and (INPUT2 is ZZ) then (OUTPUT1 
is $\mathrm{M}$ )

If (INPUT1 is NL) and (INPUT2 is PS) then (OUTPUT1 is $\mathrm{M}$ )

If (INPUT1 is NL) and (INPUT2 is PL) then (OUTPUT1 is $\mathrm{L}$ )

If (INPUT1 is NS) and (INPUT2 is NL) then (OUTPUT1 is $S)$

If (INPUT1 is ZZ) and (INPUT2 is ZZ) then (OUTPUT1 is $\mathrm{L}$ )

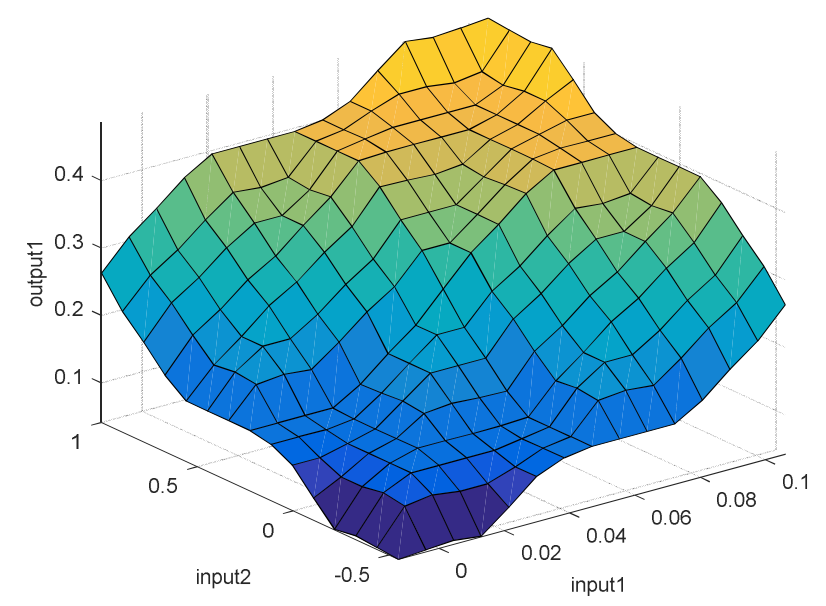

Figure 8. Surface view of type 1 fuzzy controller.

\subsubsection{Defuzzification}

Defuzzification transforming the output fuzzy linguistic variable to a real value signal. The centroid method used for defuzzification process.

\section{Simulation and Discussion}

In simulation study, we simulate the single area non-reheat thermal power plant with type 1 fuzzy controller. In this section, we compared the performances of thermal power plant using fuzzy controller with the published paper PID controller. The response of thermal power plant using PID controller of published paper is tabulated in Table 3.

Performance Comparison

A single area thermal power plant is considered for load frequency problem. A step change in load is given to a $\Delta P_{D_{L}}$. The parameters of the thermal power system are given in Table 2. We compared the responses of fuzzy controller with PID controller responses in terms of settling time, peak overshoot.

Table 2. Parameter of Single Area LFC of Thermal Power Plant.

\begin{tabular}{lll}
\hline Parameters & Symbols & Value \\
\hline Time constant of Governor & $\boldsymbol{T}_{G_{1}}$ & $0.08 \mathrm{Sec}$ \\
Time constant of Turbine & $T_{T_{1}}$ & $0.3 \mathrm{Sec}$. \\
Gain constant of Power system & $K_{P}$ & $120 \mathrm{~Hz} / \mathrm{pu} \mathrm{MW}$ \\
Time constant of Power system & $T_{P}$ & $20 \mathrm{Sec}$. \\
Speed regulation & $R_{1}$ & $2.4 \mathrm{~Hz} / \mathrm{pu} \mathrm{MW}$ \\
\hline
\end{tabular}

The proposed fuzzy controller has less settling time as compared to the PID controller of published paper and there is no peak overshoot of proposed fuzzy controller. So, the proposed fuzzy controller improved the performances of the power system. The comparative analysis of settling time of proposed fuzzy controller and references PID controller as shown in Figure 11 - Figure 12.

Table 3. Comparative Analysis of Settling time, Peak Overshoot and Peak Undershoot.

\begin{tabular}{lll}
\hline Author & Settling time & Undershoot \\
\hline Proposed Fuzzy PI & 6.221 & $-2.848 \times 10^{-3}$ \\
Padhan, 2013 [24] & 6.248 & $-9.364 \times 10^{-3}$ \\
Sadaat [25] & 27.990 & $-9.616 \times 10^{-3}$ \\
Serhat, 2012 [26] & 7.542 & $-3.875 \times 10^{-3}$ \\
Tammam, 2012 [27] & 10.839 & $-1.509 \times 10^{-3}$ \\
Hussein, 2012 [28] & 15.587 & $-5.579 \times 10^{-3}$ \\
Das, 2012 [29] & 6.694 & -0.023 \\
H Song, 2015 [30] & 9.461 & -0.018 \\
\hline
\end{tabular}

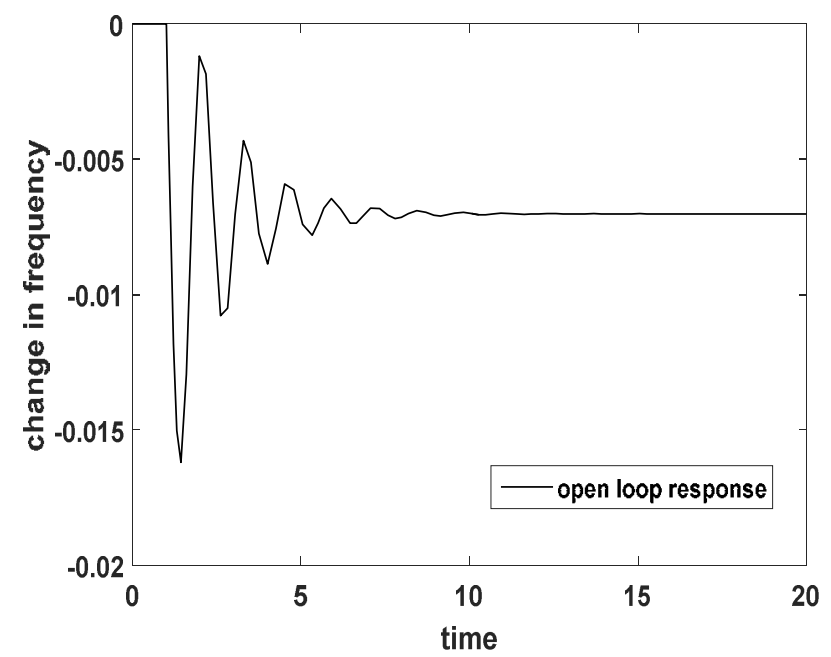

Figure 9. Frequency deviation of single area thermal power plant without fuzzy controller.

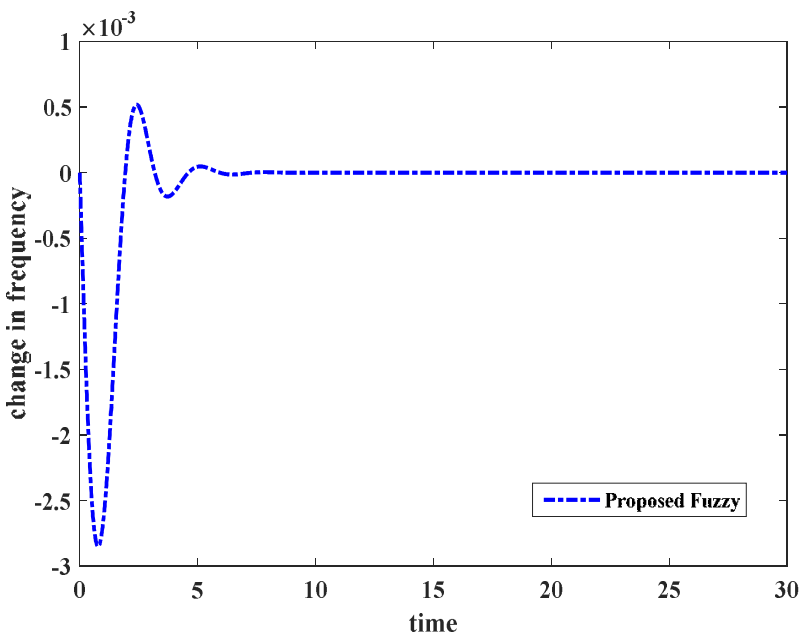

Figure 10. Frequency deviation of single area thermal power plant using Fuzzy controller due to $1 \%$ step load disturbance in power demand. 


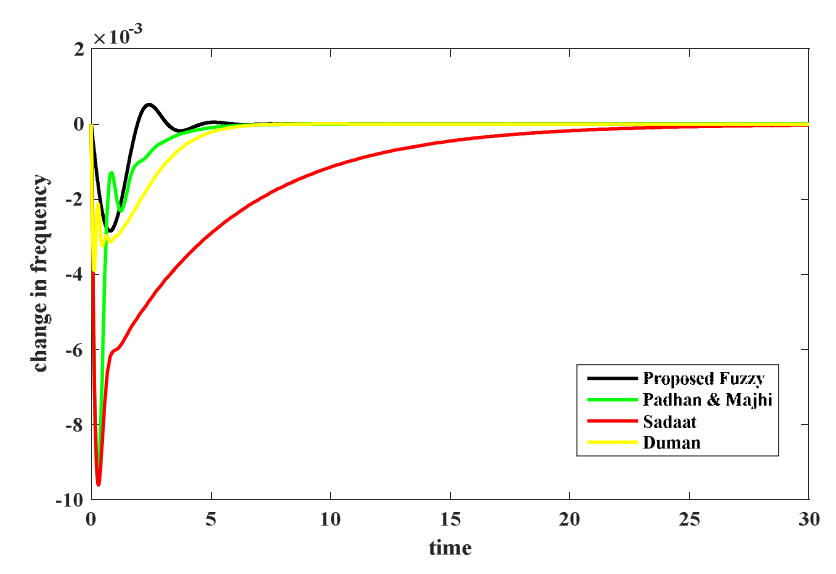

Figure 11. Comparative analysis of the response of proposed fuzzy PID with reference [25, 26, 27, 28] PID controller.

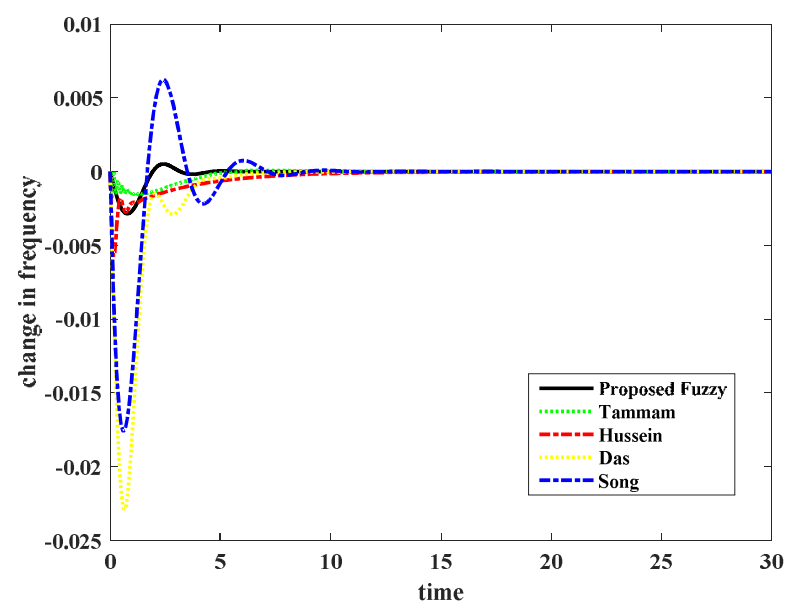

Figure 12. Comparative analysis of the response of proposed fuzzy PID with reference [22, 23, 24] PID controller.

Table 4. Comparative Analysis of Performance Indices of Proposed fuzzy controller with ref. PID controller.

\begin{tabular}{llll}
\hline Author & ITAE & IAE & ISE \\
\hline Proposed Fuzzy PI & 0.004825 & 0.003938 & $7.515 \times 10^{-6}$ \\
Padhan, 2013 [24] & 0.008529 & 0.007692 & $3.482 \times 10^{-5}$ \\
Sadaat [25] & 0.2083 & 0.03985 & 0.0001544 \\
Serhat, 2012 [26] & 0.01472 & 0.008469 & $1.912 \times 10^{-5}$ \\
Tammam, 2012 [27] & 0.01093 & 0.004877 & $5.389 \times 10^{-6}$ \\
Hussein, 2012 [28] & 0.03076 & 0.009999 & $1.809 \times 10^{-5}$ \\
Das, 2012 [29] & 0.03731 & 0.02956 & 0.0004232 \\
H Song, 2015 [30] & 0.05081 & 0.02911 & 0.0002906 \\
\hline
\end{tabular}

\section{Conclusion}

In this work, a type 1 fuzzy controller is used for controlling the load frequency of the single area non-reheat thermal power plant. A $1 \%$ step load perturbation is applied in the load demand of the power plant and analysis the system responses in terms of settling time, peak overshoot and peak undershoot. The performances of the power system using fuzzy controller is compared with the references PID controller performances. The settling time of fuzzy controller is less as compared to the conventional PID controller. There is no peak overshoot of the proposed controller. So, the type
1 fuzzy logic controller give better dynamic performances in terms of time specifications of the power system.

\section{Nomenclature}

$T_{G_{1}}:$ time constant of Steam governor

$T_{T_{1}}$ : time constant of Steam turbine

$K_{P}$ : gain constant of Power system

$T_{P}$ : time constant of Power system

$R_{1}$ : Governor speed regulation constant

ITAE: Integral of Time Multiplied Absolute Error

ISE: Integral of Square Error

IAE: Integral of Absolute Error

AGC: Automatic Generation Control

\section{References}

[1] D. K. Sambariya and R. Fagna, "Load Frequency Control of Multi-Area Hydro Thermal Power System Using Elephant Herding Optimization Technique," Journal of Automation and Control, vol. 5, pp. 25-36, 2017.

[2] R. Verma and S. Pal, "Intelligent automatic generation control of two-area hydrothermal power system using ANN and fuzzy logic," in Communication Systems and Network Technologies (CSNT), 2013 International Conference on, 2013, pp. 552-556.

[3] D. K. Sambariya and R. Fagna, "A novel Elephant Herding Optimization based PID controller design for Load frequency control in power system," in 2017 International Conference on Computer, Communications and Electronics (Comptelix), 2017, pp. 595-600.

[4] P. C. Pradhan, R. K. Sahu, and S. Panda, "Firefly algorithm optimized fuzzy PID controller for AGC of multi-area multi-source power systems with UPFC and SMES," Engineering Science and Technology, an International Journal, vol. 19, pp. 338-354, 2016.

[5] K. V. Kumar and V. Ganesh, "Fuzzy Logic Controller Based Load Frequency Control of Two Area Inter connected Thermal Power System."

[6] R. Kashyap, S. Sankeswari, and B. Patil, "Load Frequency Control using fuzzy PI controller generation of interconnected hydropower system," International Journal of Emerging Technology and Advanced Engineering, vol. 3, pp. 655-659, 2013.

[7] Y. R. Prajapatia and S. Y. Prajapatib, "A Single Area Load Frequency Control (LFC): Comparative Study Based on Integral and Fuzzy Logic Controller," IJLTEMAS, vol. 5, 2016.

[8] E. A. Daood and A. Bhardwaj, "Automatic load frequency control of Three-area power System using ANN controller with Parallel Ac/Dc Link."

[9] E. Ozkop, I. H. Altas, and A. M. Sharaf, "Load frequency control in four area power systems using fuzzy logic PI controller," in 16th National power systems conference, 2010, pp. 233-236. 
[10] Sathans and S. Akhilesh, "Fuzzy Pid Controller for Load Frequency Control of Two-Area Power System Considering Generation Rate Constraint," INTERNATIONAL JOURNAL OF ELECTRICAL SYSTEMS AND CONTROL vol. 3, pp. 43-48, 2011.

[11] L. Puran and R. Mainak, "TWO AREA CONTROL OF AGC USING PI \& PID CONTROL BY FUZZY LOGIC," International Journal of Advanced Research in Science And Engineering, vol. 4, pp. 90-96, 2015.

[12] N. S. N., "A single area load frequency control: a comparative study based on pi, optimal and fuzzy logic controllers," AMERICAN JOURNAL OF SCIENTIFIC AND INDUSTRIAL RESEARCH, 2011.

[13] E. Cam, G. Gorel, and H. Mamur, "Use of the Genetic Algorithm-Based Fuzzy Logic Controller for Load-Frequency Control in a Two Area Interconnected Power System," Applied Sciences, vol. 7, p. 308, 2017.

[14] J. R. Nayak, T. K. Pati, B. K. Sahu, and S. K. Kar, "Fuzzy-PID controller optimized TLBO algorithm on automatic generation control of a two-area interconnected power system," in 2015 International Conference on Circuits, Power and Computing Technologies [ICCPCT-2015], 2015, pp. 1-4.

[15] V. Nath and D. K. Sambariya, "Design and performance analysis of adaptive neuro fuzzy controller for load frequency control of multi-power system," in 2016 10th International Conference on Intelligent Systems and Control (ISCO), 2016, pp. 1-7.

[16] V. Nath and D. K. Sambariya, "Analysis of AGC and AVR for Single Area and Double Area Power System Using Fuzzy Logic Control," International Journal of Advanced Research in Electrical, Electronics and Instrumentation Engineering, vol. 4 pp. 6501-6511, July 20152015.

[17] D. K. Sambariya and V. Nath, "Load Frequency Control Using Fuzzy Logic Based Controller for Multi-area Power System," British Journal of Mathematics \& Computer Science, vol. 13, pp. 1-19, 2016.

[18] B. K. Sahu, T. K. Pati, J. R. Nayak, S. Panda, and S. K. Kar, "A novel hybrid LUS-TLBO optimized fuzzy-PID controller for load frequency control of multi-source power system," International Journal of Electrical Power \& Energy Systems, vol. 74, pp. 58-69, 2016.

[19] E. Yesil, "Interval type-2 fuzzy PID load frequency controller using Big Bang-Big Crunch optimization," Applied Soft Computing, vol. 15, pp. 100-112, 2014.
[20] S. Pothiya and I. Ngamroo, "Optimal fuzzy logic-based PID controller for load-frequency control including superconducting magnetic energy storage units," Energy Conversion and Management, vol. 49, pp. 2833-2838, 2008.

[21] S. M. Rakhtala and E. S. Roudbari, "Fuzzy PID control of a stand-alone system based on PEM fuel cell," Electrical Power and Energy Systems, vol. 78, pp. 576-590, 2016.

[22] M. N. Anwar and S. Pan, "A new PID load frequency controller design method in frequency domain through direct synthesis approach," International Journal of Electrical Power \& Energy Systems, vol. 67, pp. 560-569, 2015.

[23] R. K. Sahu, S. Panda, U. K. Rout, and D. K. Sahoo, "Teaching learning based optimization algorithm for automatic generation control of power system using 2-DOF PID controller," International Journal of Electrical Power and Energy Systems, vol. 77, pp. 287-301, 2016.

[24] D. G. Padhan and S. Majhi, "A new control scheme for PID load frequency controller of single-area and multi-area power systems," ISA Transactions, vol. 52, pp. 242-251, 2013.

[25] H. Saadat, "Power system analysis," PSA Publishing LLC, vol. 3rd edition, 2011.

[26] S. Duman, N. Yorukeren, and I. H. Altas, "Load frequency control of a single area power system using Gravitational Search Algorithm," in 2012 International Symposium on Innovations in Intelligent Systems and Applications, 2012, pp. $1-5$.

[27] M. Tammam, M. Aboelela, M. Moustafa, and A. Seif, "Load frequency controller design for interconnected electric power system," in 55th Annual Power Industry division Symposium POWID, 2012.

[28] T. Hussein, "A Genetic Algorithm for Optimum Design of PID Controller in Load Frequency Control," World Academy of Science, Engineering and Technology, vol. 70, pp. 956-960, 2012.

[29] K. Das, P. Das, and S. Sharma, "Load frequency control using classical controller in an isolated single area and two area reheat thermal power system," International Journal of Emerging Technology and Advanced Engineering, vol. 2, pp. 403-409, 2012.

[30] M. S. Hong, I. Wan Ismail, and A. Nor Rul Hasma, "Optimal Load Frequency Control in Single Area Power System Using Pid Controller Based on Bacterial Foraging \& Particle Swarm Optimization," ARPN Journal of Engineering and Applied Sciences, vol. 10, pp. 10733-10739, 2015. 